\title{
No modelo europeu empregados ganham
}

Na Inglaterra, a privatização iniciada no fim da década passada com a ascensão da conservadora Margareth Thatcher, é a que registra melhor indice de sucesso e não tem limites inflexíveis. A economia modernizou-se, a inflação caiu de 20 para $4 \%$ ao ano e o padrão de vida médio melhorou, mas a mudança teve um preço: o desemprego aumentou de $3 \% \mathrm{em} 79$ para $9 \%$ hoje.

Segundo o diretor do Banco N. M. Rotschild \& Sons Ltda., Anthony Fry, membro do comitê assessor da privatização do Governo britânico, a transferência de ações estatais está se dando em todos os campos. Os exemplos mais notáveis são os da Rolls Royce, General Elétric e British Petroleum, mas passa também por atividades tradicionais do Estado, como saúde, educação, transpote e abastecimento d'água.

- O maior problema que enfrentamos, nesse campo é com relação à água porque, quando menos se espera São Pedro manda chuva, desestruturando o planejamento de produção, essencial na iniciativa privada. Mesmo assim estamos estudando a forma de fazê-lo. O comentário irônico de Fry dá a exata medida da ortodoxia com que o governo Thatcher está exercendo o capitalismo liberal.

Mas há duas explicações fundamentais para o êxito do programa: primeiro, a presença do Estado era escandalosa na economia, e na privatização, os empregados ficam legalmente com fatia expressiva dos lucros da empresa - hipótese que os empresários brasileiros sequer admitem discutir. Metade da força de trabalho britâ. nica era empregada no Estado em 79 e após todo esforço privatizante ainda hoje $30 \%$ dos trabalhadores ingleses são funcionários públicos. Naquele ano, as despesas públicas representavam mais de $40 \%$ do PIB e atualmente ainda são da ordem de $30 \%$.

A tática da cooptação esvaziou os sindicatos e a oposição dos trabalhadores ao processo de privatização, mas o governo Thatcher reduziu o ritmo da desestatização por fatores que Fry não soube explicar, provavelmente ligados ao desemprego exacerbado.

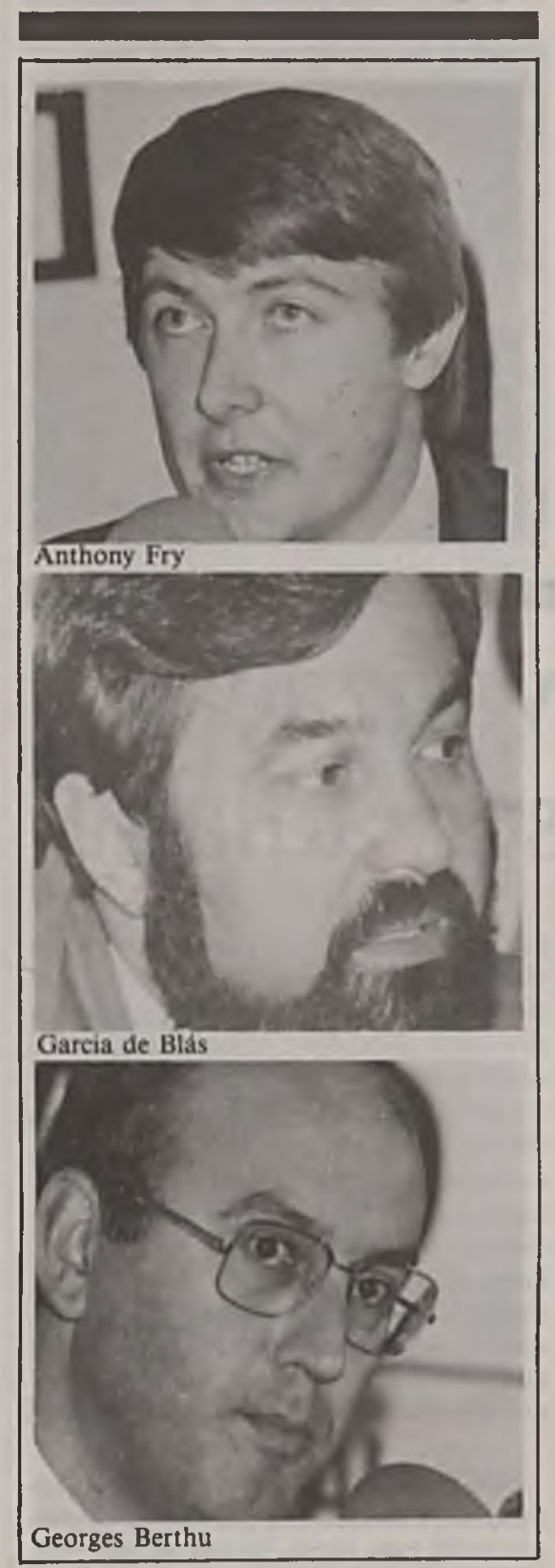

França

Na França, o processo de privatização, que jả atingiu 60 estatais, também trouxe desemprego, mas conforme relato do conselheiro Georges Berthu, do Ministério da Reforma Administrativa, hoje "os cidadãos vivem mais felizes, com mais dinhei- ro disponivel e o País equacionou vários problemas de gastos públicos".

Ao contrário da Inglaterra, a desestatização foi uma dura conquista na França e resultou de embate ideológico no Parlamento. Com a queda do gabinete socialista em 82, o Presidente Mitterrand ficou isolado e a privatização começou a ser executada, mas em bases cautelosas e muito favoráveis aos trabalhadores, que, além da participação nos lucros, têm prioridade na compra de parcela expressiva das ações oferecidas ao público.

O preço das empresas é real, rigorosamente levantado por comissão insuspeita e o resultado do negócio é aplicado na redução do endividamento estatal, atenuando os juros e o principal. Hoje, 6 milhões dos 50 milhōes de franceses são donos de ações empresariais. Os exemplos mais notáveis de privatização na França são os da Renault e a poderosa TV nacional francesa.

\section{Espanha}

Sem pressa, nem data ou presão ideológica. Assim o governo socialista de Felipe Gonzalez vai tocando o processo "lento e gradual" de privatização de vários setores ocupados pelo Estado hoje. A idéia, segundo explicou o diretor geral de Política Econômica do Ministério da Fazenda espanhol, Antônio Garcia de Blás, é limitar a ação do Estado mais à esfera da proteção social.

- Nós procuramos convencer a população e os trabalhadores, sem nenhuma precipitação, de que é melhor investir os recursos públicos nos programas sociais do que ficar tapando rombos de empresas governamentais sem objetivo de produção relevante. Na medida em que a sociedade concorda, fazemos a transferência para a iniciativa privada. As razões são estritamente práticas: reduzir o déficit público e as perdas da administração estatal com empresas improdutivas e ineficientes, explicou.

Entre outras estatais, a Espanha privatizou o Grupo Remasa (holding), a Seat (subsidiária da Fiat) e a Transmediterrânea (transportes marítimos). O Estado continua predominante nas ferrovias, construção naval, siderurgia, mineração, telecomunicações, transportes, eletricidade, petróleo e gás. 